TITLE:

\title{
A NEW BURROWER, UPOGEBIA (CALLIADNE) KIIENSIS SP. NOV. (CRUSTACEA, THALASSINIDEA), COLLECTED FROM KII, JAPAN
}

\section{$\operatorname{AUTHOR}(\mathrm{S}):$}

Sakai, Katsushi

\section{CITATION:}

Sakai, Katsushi. A NEW BURROWER, UPOGEBIA (CALLIADNE) KIIENSIS SP. NOV.

(CRUSTACEA, THALASSINIDEA), COLLECTED FROM KII, JAPAN. PUBLICATIONS OF THE SETO MARINE BIOLOGICAL LABORATORY 1971, 19(4): 243-247

ISSUE DATE:

1971-12-27

URL:

http://hdl.handle.net/2433/175720

RIGHT: 


\title{
A NEW BURROWER, UPOGEBIA (CALLIADNE) KIIENSIS SP. NOV. (CRUSTACEA, THALASSINIDEA), COLLECTED FROM KII, JAPAN ${ }^{12}$
}

\author{
KATSUSHI SAKAI \\ Seika Women's Juniro College, Fukuoka
}

With 2 Text-figures

In November 1970, a rare burrower obtained in the vicinity of Seto, Shirahama, Kii Peninsula, Japan, was submitted to me for identification through the courtesy of Mr. H. Morino, a graduate student at the Seto Marine Biological Laboratory, who happened to notice that the specimen was picked up at the net-drying yard for spiny lobster fishery on the beach of Ezura, Shirahama by Mr. Torao Yамамото, a parttime instructor of the Seto Marine Biological Laboratory and the manager of the Nanki Seibutsu Dôkôkai, the biggest society of naturalists in the southern region of Wakayama Prefecture. It was found then immediately that the specimen apparently represents a new species belonging to the subgenus Calliadne of the genus Upogebia.

I am most grateful to Mr. Yамамото for the privilege to study this very interesting specimen, which is now included in my collection.

\section{Upogebia kiiensis sp. nov.}

(Figs. 1, 2)

Holotype. One ㅇ. Sp. No. 9 in SAKaI's collection from the beach of Ezura, Shirahama, Kii Peninsula, Wakayama Prefecture, Japan; T. Yамамото col.; 8 Nov., 1970.

Diagnosis: Small species (Fig. 1), total length of female about $23 \mathrm{~mm}$. Anterior margin of carapace not tridentate, but simple and lacking anterolateral teeth. Rostrum with two apical and four lateral denticles. Dorsal surface of rostrum and anterior part of carapace with stout, yellowish, and transparent tubercles. First pereiopods chelate, symmetrical. Dactyl forming denticulated crest on cutting edge. Fixed finger slightly shorter than dactyl, with a small tubercle near the proximal end of cutting edge. Burrower inhabiting about $20 \mathrm{~m}$.

1) Contributions from the Seto Marine Biological Laboratory, No. 555.

Publ. Seto Mar. Biol. Lab., XIX (4), 243-247, 1971. (Article 17) 
Description: Rostrum slightly deflected, lower margin unarmed; apex with two contiguous, yellowish, and transparent teeth. Lateral margin of rostrum ornamented with four yellowish and transparent teeth, the posterior-most at the level of proximal margin of eye-peduncle (Fig. 2a). Anterior margin of carapace not trilobate, but simple, and lacking anterolateral teeth. Dorsal surface of rostrum and anterior part of carapace furnished with scattered tubercles which are stout, yellowish, and transparent; plumose hairs implanted at base of tubercle. Lower orbital angle unarmed. Lower anterior angle of carapace broadly rounded, lined with plumose setae.

Abdomen smooth, scanty hairs on surface. First abdominal somite triangular posterolaterally, lined with hairs on ventral margin. Second abdominal somite the broadest, slightly produced posterolaterally; hairs set in anterior $3 / 4$ of ventral margin and pubescence in posterior $1 / 4$. Third and fourth abdominal somites rounded posterolaterally; pubescence on ventral margins. Fifth abdominal somite bluntly

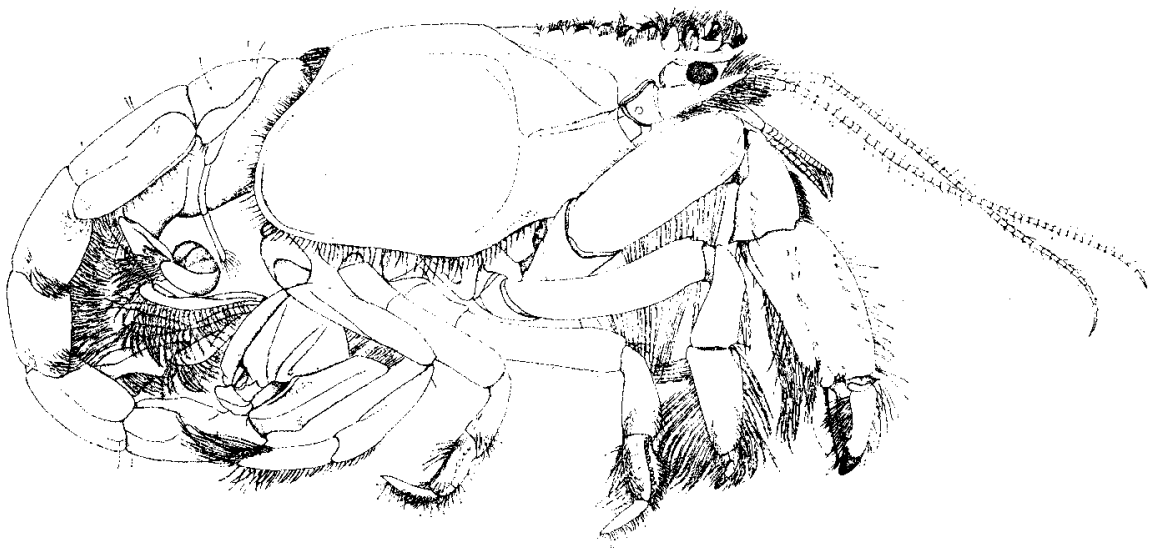

Text-fig. 1. Upogebia (Calliadne) kiiensis sp. nov., holotype, lateral view, $\times 6$.

angled posterolaterally; pubescence extending in anterior half, short hairs in posterior half of ventral margin. Sixth abdominal somite bordered laterally with truncated process in the range from middle to posterior $1 / 4$.

Telson slightly longer than sixth abdominal somite, about $4 / 5$ as long as wide. Transverse carina formed in anterior $1 / 4$ of surface, sparsely setose; lateral edges turn posteriorly along lateral margins of telson in inconspicuous longitudinal carinae, becoming obsolete posteriorly. Medial portion surrounded by above-mentioned carinae slightly concaved. Lateral margin of telson forming a slight truncated process in proximal 2/5. Posterior margin almost straight (Fig. 2c).

Eyes moderately small, apex reaching about the middle of rostrum; cornea slightly longer than stalk length.

Antennular peduncle extending beyond rostrum by distal half of ultimate segment which is about 4 times as long as penultimate segment. Dorsolateral flagellum of 

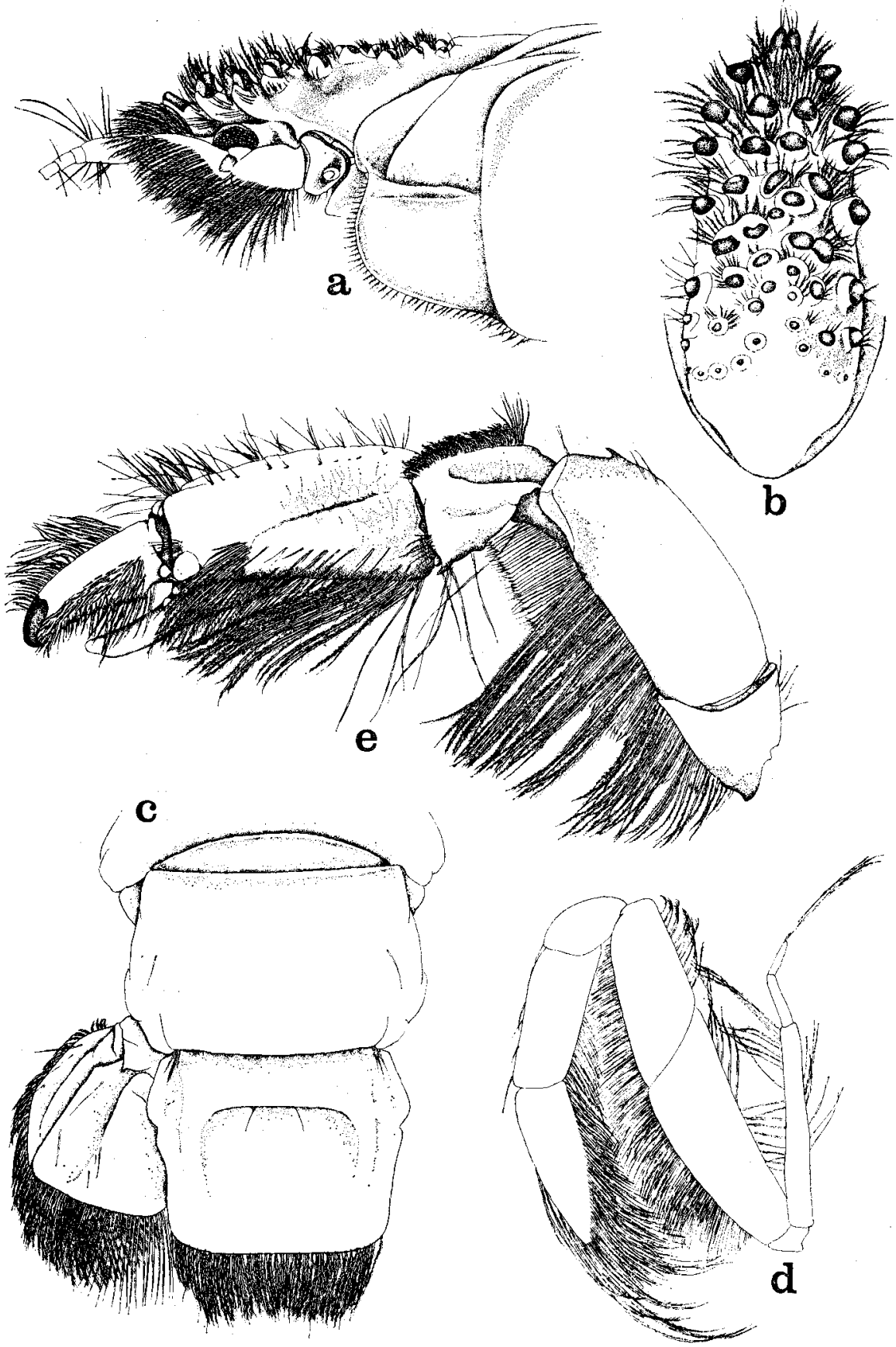

Text-fig. 2. Upogebia (Calliadne) kiiensis sp. nov.,

a. Anterior part of carapace, lateral view, $\times 10$. b. Dorsal surface of rostrum and anterior part of carapace, dorsal view, $\times 12$. c. Tail-fan, $\times 10$. d. Third maxilliped of left side, $\times 18$. e. First pereiopod of left side, $\times 12$. 
antennule nearly $1 / 5$ the length of carapace; thicker proximal portion consisting of 7 articles and occupying about $3 / 5$ of length; distal portion of 7 and apical articles, lined with hair tufts. Ventromedial flagellum slender, setigerous, slightly longer than dorsolateral one. Antennal peduncle extending beyond antennule peduncle by ultimate segment. Penultimate segment thickened, about one and half times the length of ultimate segment. Stylocerite small; apex rounded, falling short of the proximal margin of penultimate segment. Antennal flagellum slightly less than carapace length.

Third maxillipeds slender, unarmed; thick hairs on flexor margin from dactyl to carpus. Propodus about 5/6 times and carpus about half as long as dactyl. Length from dactyl to carpus subequal to that of merus and ischium combined. Ischium distinctly longer than merus. Exopod three-segmented, overreaching ischium by ultimate segment and distal portion of penultimate segment; apex bearing some long setae (Fig. 2d).

First pereiopods chelate, symmetrical. Dactyl overreaching fixed finger by distal $1 / 6$ of length, two and half times as long as wide. Cutting edge of dactyl covered by numerous setae of lower external surface, produced into crest with 6 (left)-7 (right) denticles larger proximally; proximal denticle much more developed than others, placed at proximal $1 / 4$ of length. Upper surface of dactyl marked with smooth broad carina and setigerous band, the latter running along the interior side of the former. Lower external surface covered by two rows of numerous setae, rows fusing into one in distal half; a tubercle on the proximal margin of chela. Internal surface delimited on upper margin by a row of 9 tubercles, diminishing in size distally. Fixed finger produced from the distal half of lower margin of propodus, with a tubercle near the proximal end of cutting edge. Propodus one and half times as long as dactyl, slightly less than twice as long as wide, a prominent tubercle just on the joint with dactyl. Upper surface of propodus implanted with four rows of scanty hair tufts; internal surface with a row of hair tufts in parallel with upper margin; external surface lined with minute setae obliquely from upper proximal to lower distal to join hairy band found on lower surface. Carpus slightly longer than half of the propodus length; upper surface lined with thick plumose hairs on exterior margin, a distinct subterminal tooth and two other small teeth on interior margin, one of the latter just below and the other just above the former; a subterminal tooth on lower margin, too. Merus twice the carpus length, with a subterminal tooth on upper margin.

First pleopods slender, consisting of two subequal segments; second to fifth pleopods broad in shape.

Type locality: Most probably in the vicinity of Seto, where the gill-nets for spiny lobster fishery are set in the autumn season about $20 \mathrm{~m}$ deep, Shirahama, Wakayama Prefecture, Japan.

Discussion: Eleven species of the subgenus Calliadne have been reported from localities in the Indo-West Pacific region. In Japan, the only one species, Upogebia (Calliadne) isodactyla (ORTMAnN, 1891) is reported from the Inalnd-Sea of Japan by 
Nakazawa (1927, 1947), but this species has already been known as Upogebia (Calliadne) savignyi (Strahl, 1861) (Nobili, 1906) occurring from the Red Sea to the east coast of South Africa (DE MAN, 1927, 1928; BARNARD, 1950), inhabiting often inside the sponges (Nobili, 1906; Stebbing, 1910; Barnard, 1950).

On the other hand, no more specimen of NAKAzAwA's isodactyla has been found in Japan; the upogebiids from the Inland-Sea and some other localities are mostly Upogebia (Upogebia) major (DE HAAN, 1849), together with some $U$. (Upogebia) yokoyai MaKarov, 1938 intermingled (SAKaI, 1968).

Then, the present record of a distinct form belonging to the subgenus Calliadne must be very significant in the upogebiid fauna of Japan.

This new species distinctly differs from any previously known species in lacking the anterolateral teeth of the carapace, though it resembles both $U$. (Calliadne) nitida (A. Milne-Edwards, 1868) from the Cape Verde, the Atlantic Ocean and U. (Calliadne) bowerbankii (MreRs, 1884) from Fremantle, south-west Australia, in having two apical contiguous denticles of the rostrum. In these exotic species, however, the tubercles on the dorsal surface of the rostrum and anterior part of the carapace are more numerous and smaller in size than in the present new species, and there are paired anterolateral teeth, each separated from the rostrumb by an interspace.

\section{LITERATURE GITED}

Barnard, K. H. 1950. Descriptive catalogue of South African Decapod Crustacea. Annals of the South African Museum. 38: 522-523. Text-fig. 97.

DE MAN, J. G. 1927. A contribution to the knowledge of twenty-one species of the genus Upogebia LeAch. Capita Zoologica. 2 (5): 5-12. Pl. 1, figs. 1, 4.

1928. The Decapoda of the Siboga-Expedition. Part 7. The Thalassinidae and Callianassidae collected by the Siboga-Expedition with some remarks on the Laomediidae. Siboga-Expeditie. 39 a 6.

Miers, E.J. 1884. Report on the Zoological collections made in the Indo-Pacific Ocean during the voyage of H.M.S. "Alert" 1881-1882. :282.

A. Milne Edwards 1868. Faune carcinologique des iles du Cap-Vert. Nouvelles Archives du Muséum d'Histoire Naturelle de Paris. 4: 63-64. P1. 18.

Nakazawa, K. 1927. Anomura. In: Nippon Dobutsu Zukan (Eiguraro de Japanaj Bestoj), Tokyo. :1037. Text-fig. 1998.

Nakazawa and Kubo 1947. Macrura. In: Nippon Dobutsu Zukan (Illustrated encyclopedia of the Fauna of Japan), revised edition, Tokyo. :755. Text-fig. 2175.

Nobili, G. 1906. Faune carcinologique de la Mer Rouge. Décapodes et Stomatopodes. Annales des Sciences Naturelles, Paris. 4: 98-100.

Ortmann, A. 1891. Die Decapoden-Krebse des Strassburger Museums. III Die Abtheilungen der Reptantia Boas; Homaridea, Loricata und Thalassinidea. Zoologischen Jahrbüchern. Abtheilung für Systematik, Geographie und Biologie der Thiere. 6: 55. PI. 1.

SAKAI, K. 1968. Three species of the genus Upogebia (Decapoda, Crustacea) in Japan. Journal of Seika Women's Junior Colleg. 1: 45-50, Text-fig. 1.

Stebring, T. R. R. 1910. General catalogue of South African Crustacea. : 371.

STRAHL 1861. Über einige neue von Hrn. F. JAGor eingesandte Thalassinen und die systematische Stellung dieser Familie. Monatsberichte der Königlichen Preusss Akademie der Wissenschaften zu Berlin. 1862. :1064-1072. 